\title{
The Crisis of Kingship in Late Medieval Islam Persian Emigres and the Making of Ottoman Sovereignty by
}

Christopher Markiewicz (Cambridge Studies in Islamic Civilization, Cambridge, United Kingdom: Cambridge University Press, 2019), 364 pp., ISBN: 978-1108492140; \$89.70 (hb), doi: $10.1017 / 9781108684842$

Christopher Markiewicz's The Crisis of Kingship in Late Medieval Islam is an impressive contribution to the history of the late medieval world. At its core, this study is about Persian scholar and chancellor Idrīs-i Bidlisī, his life story, experiences in the Aqqoyunlu and Ottoman courts, and his multiple works, particularly of his history Hesht Behisht. However, this book is a lot more than Bidlisî's life and times. Markiewicz brilliantly weaves together various political notions and ideas that occupied the $15^{\text {th }}$-century statesmen and intellectuals, and how these notions came to be adopted by all the Muslim polities of the period.

The leading argument of the book is a strikingly clear one: the dissolution of the Abbasid Caliphate in the hands of the Mongols in the $13^{\text {th }}$ century, as well as the fragmentation of the Chinghissid Ilkhanate in the $14^{\text {th }}$ century, left various successor states scrambling for means, tools, and ideas to legitimize their rule. Even though, one of the fundamental conditions for the caliphate had been Qurayshid descent for most Sunnī jurists, very few late medieval Islamic dynasties had any reasonable links to the Prophet's clan. In the absence of Qurayshī descent, succession from and relation to the Chinghissid family could have been an alternative way to assert one's right to rule. As a matter of fact, Timur did just that. However, how about the rising dynasties of the $14^{\text {th }}, 15^{\text {th }}$, and early $16^{\text {th }}$ centuries, namely the Ottomans, Aqqoyunlus, the Uzbeks, and the Safavids? How did they legitimize their rule? Markiewicz contends that the intellectual climate of the $15^{\text {th }}$ and early $16^{\text {th }}$ centuries was a lot more organic and interwoven than that has been previously assumed. Chancellors, intellectuals, scholars

Ilahiyat Studies

Volume 12 Number 2 Summer / Fall 2021
p-ISSN: 1309-1786 / e-ISSN: 1309-1719

DOI: $10.12730 / 13091719.2021 .122 .230$

To cite this article: Erginbaş, Vefa. "The Crisis of Kingship in Late Medieval Islam: Persian Emigres and the Making of Ottoman Sovereignty by Christopher Markiewicz." Ilabiyat Studies 12, no. 2 (2021): 307-310. https://doi.org/10.12730/13091719.2021.122.230 
who worked for one court at one time did not hesitate to offer their services to another. They felt very little unease doing that. Idrīs-i Bidlisī was a chancellor in the Akkoyunlu court. With the dissolution of the Akkoyunlu and the rise of the Safavids, ${ }^{1}$ he left Iran and self-exiled himself in the Ottoman capital. Markiewicz argues that Bidlisī carried with himself various notions about kingship, the universe, and faith. He deployed these notions in his magnum opus, Hesht Behist (The Eight Paradises). In this book, he presented the Ottoman sultans as khalîfa-yi rabmmānī (vicegerent of God) and mujaddids. Markiewicz argues that the former concept that Idrīs-i Bidlisī first encountered during his service in the Akkoyunlu court became particularly useful to define Ottoman rule. Markiewicz calls this a "new vocabulary of sovereignty," which was first formulated in the Timurid court, and which was eventually embraced by all Muslim polities of the time. This "new vocabulary" was based on "the claims of authority in cosmological doctrines that anticipated the ordination of one individual to usher in a new era of universal justice, order, and peace." (2) $15^{\text {th }}$ century was a fertile ground to bring about these innovative notions: Sufi networks and millenarian movements ushered a new age of intellectual vibrancy, which was transmitted easily through a fractured political landscape. (5) Even though the Ottomanists are inclined to think of the Ottoman Empire as an isolated self-rising polity, Markiewicz vehemently opposes this notion. The Ottomans were never free of the political "anxieties" of the age. "The Ottoman claims to legitimacy that solely based on the Ottoman Sultan's status as warrior of the faith, Oguz descendant, or Seljuk heir failed to accommodate the increasingly complex terrain in which the Ottomans operated and exercised power." (11) In this context, an emphasis on the "sultan" himself became more important than the previous cultural manifestations of kingship. Markiewicz focuses on the life and times of Idrīs-i Bidlisī to explore how these ideas were created and adopted. The Ottomans and Akkoyunlus did not magically agree on "similar conceptions of sovereignty." Markiewicz asserts that migrants like

Markiewicz persuasively argues that Idrīs-i Bidlisis's departure from Tabriz was not necessarily because of the rise of Ismail and the Safavid Shiism but rather because of his unease with the years of turbulence and frequent reversals of fortune he experienced during this period. Otherwise, confessionally speaking, Bidlisī was quite comfortable with fluid notions of Islam, oscillating between Sunnism and Shiism (68-71) before his emigration. 
Idrīs-i Bidlisī brought and circulated "specific formulations of kingship" and shaped the Ottoman political discourse with those notions.

In history, Bidlisĩ found the medium to explore the aforementioned notions of kingship. He participated in the debate between the "Arabophone" and "Persophone" historians on the meaning and purpose of history. (21) Bidlisī advanced the concept khiläfat-i raḅmāni, which was based on "astrological, mystical, and philosophical" conceptions rather than exclusively relying on more traditional ways to legitimize the Ottoman rule such as their role in ghaza, or hailing from the Oghuz or Seljukid lineage. Khiläfat-i rạ̣māni offered Bidlisī a "coherent vision of kingship" that personified in the Ottoman sultans. The concepts such as sabibkiran and mujaddid also gained wide currency at this time to define the Ottoman sultans. Scholars like Bidlisī were responsible for the wide circulation of these concepts. Markiewicz further argues that Idrīs-i Bidlisī's influence on future Ottoman historians was immense. The Eight Paradises has almost a hundred extant copies all around the world, whereas for instance Tursun Beg's Tārîkh-i Abü l-Fatḥ had only a few. Even though subsequent historians found Bidlisī's prose heavy and ornate, he did influence the literary expectations of the subsequent generation of historians as many of them tried to emulate Bidlisis's literary style.

Christopher Markiewicz's book is one of the best studies of the fifteenth-century Islamic world and notions of kingship and how these notions were not born out of abstract speculations but rather brought about and circulated by scholars who emigrated from one court to another. Markiewicz's bibliography is near exhaustive; he uses all three languages of the Ottoman intellectual world, Turkish, Arabic, and Persian with ease. The book successfully places the Ottoman Empire within the wider "ecumene" of the Islamic world. We often think about the development of the Ottoman Empire as an independent and isolated process, connected to their expansion to the West while downplaying their relations with the Muslim Empires and reducing their relationship with these empires to a series of conflicts. Markiewicz displays how intellectuals such as Bidlisi influenced the Ottoman political culture and in turn perhaps influenced by it.

There are not many faults one can find with this study as it is wellwritten, well-argued, and well-sourced. One general issue, not specifically with this study, but with any intellectual effort that takes at its center an individual is the risk of the author overemphasizing the 
importance of his subject. For instance, one could credibly argue that Kemalpaşazade and Neşri had an equally strong influence on future Ottoman historical writing. As a matter of fact, Abdülkadir Özcan is of the opinion that Hesht Behist's information is mostly taken from Neşri's Kitāb-i Jihānnuma $\bar{a}^{2}$ which makes Neșri's role more important than Bidlisī's in shaping future historical scholarship. If we especially consider the ornate writing style of Bidlisī and how it was criticized at the time of its production, the issue of his influence becomes even more problematic. Bidlisis's very clear influence can be however seen in Sadeddin's Tāj al-tawārīkh so much so that Sadeddin's work is often considered to be a translation and continuation of Bidlisì's work. The reader hopes to see more in the study about the extent of this influence. Even though Markiewicz mentions Sadeddin's work and Bidlisì's influence on him in passing, he does not dwell much on this subject.

This book is an excellent intellectual history like Cornell Fleischer's now-classic study Bureaucrat and Intellectual in the Ottoman Empire: The Historian Mustafa Ali. Christopher Markiewicz seems to be the intellectual heir to Cornell Fleischer's legacy among many of his very successful students. The Crisis of Kinship is a very promising study with many questions answered rather than obscured regarding the Ottoman political ideology. If read along with Hüseyin Y1lmaz's recent work Caliphate Redefined: The Mystical Turn in Ottoman Political Thought (Princeton University Press, 2018) and Shahzad Bashir's Messianic Hopes and Mystical Visions (University of South Carolina Press, 2003) The Crisis of Kingship would fill a very visible gap in the study of the late medieval Islamic world. I wholeheartedly recommend this work to anyone who studies this period.

\section{Vefa Erginbaş}

Providence College, RI-USA erginbas@providence.edu

\section{REFERENCES}

Özcan, Abdülkadir. "Heşt Bihişt.” In Türkiye Diyanet Vakfi İslam Ansiklopedisi (DIA), XVII, 271-273.

2 Abdülkadir Özcan, "Heşt Bihişt," in Türkiye Diyanet Vakfi İslam Ansiklopedisi (DİA), XVII, 271-273. 